\title{
Research Paper: Spatial Analysis of Non-Resident Agriculture Holders in Rural Areas of Iran
}

\author{
Mohammad Reza Rezvani $^{1^{*}}$, Bahman Tahmasi², Masoumeh Ghorbani \\ 1. Professor, Department of Human Geography, Faculty of Geography, University of Tehran, Tehran, Iran. \\ 2. PhD Student, Department of Human Geography, Faculty of Geography, University of Tehran, Tehran, Iran.
}

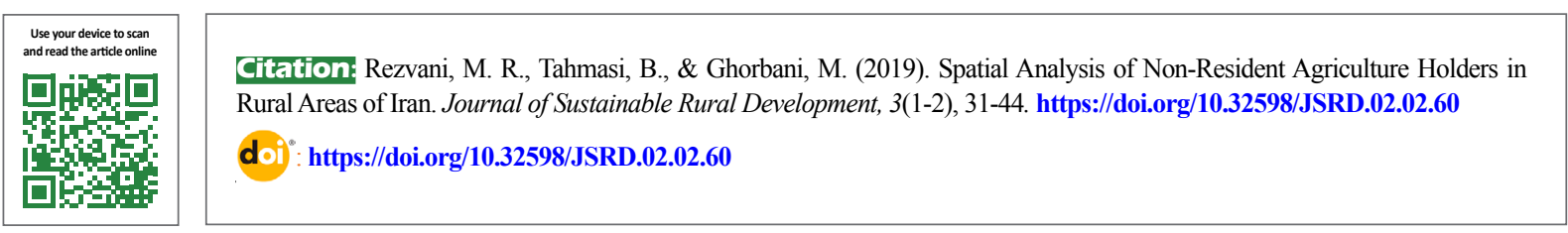

Article info:

Received: 23 July 2019

Accepted: 18 Nov. 2019

\section{Keywords:}

Spatial analysis, Non-resident agriculture holders, Rural areas, Iran

\begin{abstract}
Purpose: The present study aims at describing the general status of non-resident agriculture holders in rural areas. Moreover, it tries to not only investigate the hotspots of non-resident agriculture holders but also analyze its spatial pattern across the county of Iran. Besides, the current study will analyze the most effective factors on forming each hotspot across the Country.

Methods: The study is a kind of descriptive-analytic one. The data are adopted from agriculture census of Iran Statistic Center in 2003 and 2014. They have been analyzed by spatial statistic techniques in GIS environment.

Results: The findings reveal that the spatial distribution of non-resident agriculture holders is heterogeneous across the Country. The findings from spatial statistics indicate the existence of two main hotspots of non-resident agriculture holders across the towns; the first hotspot has been formed in central Iran and the northern regions of the Country, while the other one has been formed in the west.

Conclusion: The increase of non-resident agriculture holders in rural area which has been formed in the frame of rural-urban linkages, leads to increase smallholdings, decrease agriculture productivity, and weaken the balance between rural population and agriculture capacities for production and employment. Therefore, it acts like a barrier in the process of Sustainable rural development.
\end{abstract}

\section{Introduction}

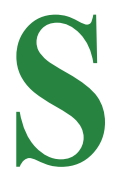

table agricultural development globally is of great importance especially in economic planning and human development issues (Xu et al., 2006). In fact, agriculture section is worth noting due to achieving millennium development goals whose first goal is eradicating extreme poverty and starvation in the world (Leunufna \& Evans, 2014). Since agriculture section is essential to meeting people's nutritional needs, providing raw materials for industry, employing and creating income, and the stabil-

* Corresponding Author:

Mohammad Reza Rezvani, PhD

Address: Department of Geography and Rural Planning, Faculty of Geography, University of Tehran, Tehran, Iran.

Tel: +98 (912) 2180492

E-mail: rrezvani@ut.ac.ir 
ity and continuity of its growth is considered as the main factors leading to social stability and economic growth (Gong \& Lin, 2000). Therefore, the reinforcement of agriculture section is regarded as a base which is absolutely needed to achieve the development goals especially in developing countries (Leavy \& Smith, 2010).

Agriculture section is facing different challenges such as climate changes, urbanization, and environmental issues nowadays. However, the status will be intensified, as the demand for food increases. It is estimated that the population growth will have increased to 9 billion by 2050 (Chen et al., 2011). Following a statement from a conference on agriculture and the environment in Netherland, FAO has planned to pay more attention to agriculture and food security since 1991 (FAO, 1991).

Despite the special role of agriculture in the economic structure of Iran and its inseparable linkage with the life of the population living in villages, this section faces many challenges and shortages leading to the inefficiency of production section and agriculture economy in recent decades. The challenges include using traditional tools in the process of production, land segmentation, dispersed lands, small-size lands available for holders, and the low efficiency of production factors and nonaffordable cultivation (Shateri et al., 2013). Improper holding in agriculture section of the country is somewhat affected by agriculture holding systems. They are known as the main lever of all agricultural activities in Iran. As a result, any change in cultural production system is not possible without the change in holding systems (Toupchi et al., 2011).

However, the effect of a growing phenomenon called either absent ownership of lands or non-resident agricultural holders has been of great importance. Being managed in landlord-peasant system, rural communities used to be a closed community before land reform which had an extremely weak communication with surrounding communities, especially cities. Holders and great owners used to try to stabilize their strength by maintaining traditional isolation of rural communities. As a matter of fact, they restricted the farmer's relationship with market by observing and controlling the farmers' exchanges in local cities. However, as land reforming emerges, new patterns of land ownership have also appeared which are dependent on different changes. In recent decades, as the migration of villagers, who owe lands, to cities increases, the number of non-resident agriculture holders also increases leading to a lot of consequences in rural areas and agriculture section. Therefore, the present study aims at investigating the general status of non-resident agriculture holders across the Country, provices and towns. Moreover, it tries to identify regions and hotspots of non-resident agriculture holders using spatial statistic methods. Besides, the paper will analyze the most effective factors on forming each focus hotspots and the present spatial pattern across the country.

\section{Literature Review}

Ownership is the foundation of agriculture holding systems. Therefore, the most important fundamental features of each holding system are determined based on the form of the entities, ownership relationships, and main means of production in that system. As a result, ownership is of considerable attention in studying and analyzing the agriculture holding systems, based on the kind of ownership system and its holding (Hosseini, 2009).

Holding system is a collection of customary, juridical, technical, managerial procedures in integrating and using production factors (work, land, water, tool, money, ...) in the frame of Labor and Social Affair Organization to both produce agricultural yields and send them to market. In other words, holding system is a purposeful system to produce agricultural yields, and livestock products whose marketing for profitability is done systematically by using natural resources, and efficient human force (Azkia, 2008). The experts have classified holding systems from different aspects emphasizing the ownership of lands.

Meelor classifies the holding systems into 5 classes in term of the farmer ownership of lands including landlord and peasant system, the system of great owner farms (larger than landlord and peasant system), cooperative system (volunteer actions of some unanimous farmers sharing the same attitudes), collective system (collective ownership) and state system (Spedding, 2012).

Chaynov divides the holding systems into 4 categories including family or farmer holding systems, feudal system, share system and collective system (Chaynov, 1977).

Galeski and Wilkening emphasizes on collective holding systems. They categorize group farming in rural communities in 4 groups including collective farming formed by believers in a particular school such as religious communes, collective farming of landless families, group farming, state collective farming, group farming of farmers (Galeski \& Wilkening, 1987). 
Based on the aforesaid categorizations, it is possible to infer a general classification of The peasant system (Smallholding, sharing farming, renting, and ownership), small business enterprises, sharing farming, traditional cooperatives, production cooperatives, collectives, land capitalism, agro-industries from agriculture holding systems. In Iran, the agriculture holding systems before land reform used to include landlord peasant, renting, mechanized, state, and family systems (Hosseini, 2009).

Before 1962 when Land reform began, territorial ownership and demographic composition patterns divided rural population of Iran which was two third of the population into 3 classes:

Smallholder peasants and small land owners, $25 \%$ of rural population

Farmers who had Nasaq right ${ }^{1}$ and families with renting lands, $40 \%$ of rural population

Landless villagers, $35 \%$ of rural population which were called colonizer who were mostly in low class rural population (Ashraf, 2004).

In 20th century in Iran, the ownership of the villages was the criterion to evaluate the ownership of the lands rather than the area of the lands they owned. The landlords were in 2 groups: the group of seigniors, great landlords, which included all individuals and entities who owned a complete village at least (Hooglund, 2002). This group was mainly absent landlords who were living in cities. The related affairs of the village were assigned to a steward and chief (Shahverdi, 1994). According to the statistic of Land Reform Organization, the number of seigniors was reported as 32 thousand, and they had about 10 percent of the farming land, although they were approximately 2 percent of all landlords (Hooglund, 2002). However, this number is not the same around the country depending on different factors like accessing water and irrigation system. As Lambton reports that there was no smallholder in some places like Kerman due to expensive irrigation. As a matter of fact, not only was both the length of qanats and the distance to surface too long, but the soil in which the qanat was flowing was soft. Therefore, the annual cost of repair was not affordable enough for farmers (Lambton, 1983). Second group is smallholders group including the indi-

1. Traditional and customary right to use water and land resources and participate in agricultural activities in traditional agricultural production relationships (Encyclopedia of urban and rural management,800). viduals whose property was less than a complete village. smallholders were divided into 2 main groups; farmers and non-farmers. The smallholders who were not doing farming themselves including businessmen, capitalists, bureaucratic, teachers, business owners, clergymen, and professionals who were living in cities used to manage their lands in coordination with seigniors. Like seigniors, non-farmer smallholders often used to share the ownership of a village with at least one partner, the ownership of large villages were likely to be shared among 10 owners. Unlike non-farmer smallholders absent smallholders, farmer landlords personally did farming affairs. The number of farmer Owners was supposed to be half of the smallholders, $5 \%$ of all rural population, although they were completely poor. Their lands were small and they rarely achieved more than their livelihood. Although, smallholders farmer socially had better status than the landless farmers, they did not have the position and influence of absent landlords, whether big or small (Hooglund, 2002). Absent smallholders mainly included urban retailers who drove a part of the profit from the business into the estates adjacent to cities which sometimes had proper profit for these absent landlords. Moreover, despite economic advantages, the owners used to be interested in snuggling there against the city heat in summer. For example, most of the mountainous villages in Mt. Alborz located in the north of Tehran have been owned by urban absent landlords (Lambton, 1983). The number of absent smallholders has been estimated as 300 to 350 thousand, while the farmer smallholders have been 800 to 850 thousand (Abrahimian, 1996). Based on the previous studies, it can be concluded that the properties of Smallholding were exclusively in the regions which had less fertility and the fertile regions were mostly controlled by absent seigniors (Lambton, 1983).

Various land-holding methods has led to special kind of rural urban relationships. Presenting rent-capitalism, Hans Bobek believes that economic relationship between urban and rural areas is one-sided benefitting urban centers. In his point of view, the cities exploit the economic resources of the rural areas under their control using different strategies without investing any contribution from the financial resources of this relationship. Bobek believes that traditional cities of Iran are living by exploiting periphery rural areas, so they receive their motivation for their economic growth. In one hand, this theory is based on the traditional relationship of ownership and the occupation of rural areas, but on the other hand, cities are recognized as a shopping center for crops (Ehlers, 2010). 
In this regard, Ehlers indicates that due to the prevalence of Sharecropping in Iran, the transfer of agricultural production benefits from rural areas to cities, as a residence of great landlords, is a major feature of the socio-economic structure of Iran urbanization.Besides, Ehlers believes that the cities in Iran are mostly born by the peripheral environment which helps them achieve the total ability to grow both economically and socially. In fact, the traditional relationship of ownership in rural areas and the system of preselling crops are the creator of the relationship between cities and villages (Ehlers, 2001).

Unlike the previous theory, Wirth considers the cities as a factor for the development of rural productions by not only buying and consuming rural crops and materials but also providing some services for the villagers (Saeidi, 2011). Advocating Wirth's theory on the dependency of urban life on the relationships with surrounding rural areas, some believe that cities are the creator of rural areas, since absorbing the extra production of crops gets the migration of rural population to urban region intensified, on the one hand, and has the cities and urbanization developed on the other hand in recent decades (Taleb, 1994).

In Iran, holding relations and land ownership were affected by the occurrence of land reform. Land reform program passed the traditional landlord-peasant dependencies in Iran in 70s introducing innovative methods of land relations to rural areas (Hooglund, 2002). Land reform have the whole Nasaq or a part of that sold to the farmer with title deed. Therefore, land reform have conveyed the ownership of 6 to 7 million hectare of farming land (About 52 to 62 percent of all farming land) to tenant farmers and farmers who had Nasaq right (Kargar Esfand Abadi et al., 2017).

The added holding systems after land reforms include the rural production cooperative, agricultural corporations, cultivation and industries. After the Revolution, jurisprudence and juridical disputes led to disagreements and different short-term policies. Eventually, land division of seigniors stopped and the government assigned pastures to equity sharing units, rural production, mechanized, farming corporation, cultivation and industry for holding. As a result, The Islamic Revolution of Iran, as a social event, led to some changes in the holding systems before the Revolution (Hosseini, 2009). In the following years after land reforms, the employees of agriculture section dropped from $76 \%$ in 1956 to $63 \%$ in 1976 which was mainly due to the expansion of business holdings, mechanization of agriculture and the growth of industry and service sections (Taleb \& Anbari, 2005). There were great changes in the methods of agriculture holding in this period. In general agriculture census, Iran Statistic Center divides agriculture holders into 4 groups including usual resident normal family, non-resident holders, non-resident normal family, and official companies and institutes (statistic center, 2014). The related definitions to agriculture holdings are presented in the following part.

Agriculture holder is a juridical or natural person who manages agriculture holding affairs and its technical and economic responsibilities alone or in the participation of others. Besides he is directly contributed to profit and loss.

Agriculture holding is an economic-productive agriculture entity which is under the management of an entity. This management is carried out by either the member of one or several families (natural individuals) or a public company or institute (juridical person). If a production entity around some villages or cities has agricultural lands or installations, each part in a village or city is considered as an agriculture holding. Holding land can be either continuous or separated in far or near distance. The appropriate agricultural activities in holding are one or a combination of 2 main activities, cultivation of crops and animal breeding, to achieve economic holding. The cultivation of crops can be done in either an open or closed place, in land or a vase including raising mushrooms.

Agriculture holding land is any occupied land for agriculture holding. The lands such as stores, the place for keeping agriculture machines, the roads inside the holding, the place for livestock and poultries, pasture, and occupied jungles which are not directly applied in agriculture production are also considered as holding lands. Public pastures which are not occupied in holding while are used will not be considered as holding lands. If the habitat of the holder is located inside the holding area, it will be considered as a holding land. However, residential houses located in a city or residential context of a village will not be considered as holding lands even if it is a place for agricultural activities of a family.

Land-based holding is a kind of agriculture holding whose activities are done in a place which, according to the aforesaid definition, is agriculture holding.

Landless holding is a kind of agriculture holding whose activities are done in a place which is not considered as an agriculture holding land based on the aforesaid definition. For example, either the holding belongs to a fam- 
ily whose activities are done inside a residential unit, or the stock raising belongs to a family which uses public lands and pastures to keep their livestock (statistic census, 2014).

In addition to studying the historical development of agriculture holdings before land reform and recognizing the most significant agriculture holding systems introduced by different experts, the present study aims at reviewing the experts' attitudes about the effects of different agriculture holding methods on rural area. Furthermore, the information related to non-resident agriculture holders will be analyzed based on the latest definitions and present categorization of different kinds of agriculture holdings by statistic center.

\section{Methodology}

The current study is a kind of descriptive-analytic one in which the studying population is all non-resident agriculture holdings of Iran. The study has analyzed non-resident agriculture holdings in 3 scales; national, provincial, and county. However, the main core of the study is the spatial analysis of non-resident agriculture holders across the county. The data were acquired from public agriculture census of Iran Census Center in 2014 and 2003.

The data were analyzed in the environment of Arc GIS using spatial statistic techniques. Spatial autocorrelation (Morans I) and Hot Spot Analysis (Getis-Ord Gi*) were applied to investigate the spatial pattern of the studying variable and hotspots respectively.

\section{Spatial Autocorrelation (Morans I)}

Presented by Morans in 1948, Morans index is one of the most significant tools used to evaluate spatial autocorrelation. General Morans is a tool to determine the spatial pattern of data to be either dispersed, clustered or random (Cliff \& Ord, 1981; Mansourian et al., 2018) varies from +1 and -1 . The spatial pattern is proved to be clustered, as Morans is +1 or near. When Morans is near -1 or near, then the spatial pattern is supposed to be dispersed. The spatial pattern will be random if Morans is 0 proving lack of relationship in the pattern. Final conclusion is found only if $\mathrm{z}$ score and $\mathrm{p}$ value are found for Morans index (Kumari et al., 2019).

It is hypothesized that general Morans is basically made of independent features whose values are formed randomly in geographical space. When $\mathrm{p}$ value is bigger than 0.05 , the basic hypothesis is accepted which means that the data values are made randomly in geographical space. As p is smaller than 0.05 and $\mathrm{z}$ score is negative, the basic hypothesis is rejected. Therefore, it is concluded that high and low values of the data indicates dispersed pattern. Similarly, when $p$ is less than 0.05 and $\mathrm{z}$ score is positive, then random pattern is rejected again. It turns out that high values and low data in geographical space proves clustered pattern (Yang et al., 2018).

\section{Hot Spot Analysis (Getis-Ord Gi*)}

Getis-Ord Gi, known also as hot spot analysis, is a method to analyze spatial tendencies (clustering) based on the features of spatial data (points or district) (Getis \& Ord 1996; Mitchel, 2005). Adopted from general statistic $\mathrm{G}$, this method is a global way to measure spatial autocorrelation in a region. General statistic $\mathrm{G}$ is a unique statistic for the whole calculating. However, statistic Gi is an index to investigate local autocorrelation; it helps to figure out how spatial autocorrelation is different in a region. This method deals with assessing each feature according to similar high or low values of adjacent features in a special geographical distance. The output of Gi statistic is a map indicating spatial status of spatial clusters in the studying region. Positive values of Gi prove spatial dependency among high values, while negative values of Gi sign spatial dependency among low values determining whether a special feature belongs to a hot spot (spatial cluster from high values of data), cold spot (spatial cluster from low values of data) or an output with high surrounded values with low values of data and vice versa (no spatial dependency) (Peeters et al., 2015).

\section{Findings}

The present paper has analyzed non-resident agriculture holders in national, provincial and county levels. The total features of non-resident holders have been studied in national and provincial levels, whereas in the county level, in addition to the total features of non-resident holders, the spatial patterns of non-resident holders are studied in spatial area of Iran by applying spatial statistic methods.

\section{The Features of Non-resident Agriculture Holders in National and Provincial Levels}

The findings from agriculture census in 2014 shows that there were 4032467 agriculture holders including $0.22 \%$ official companies and institutes, $0.40 \%$ non-resident normal family, $23.39 \%$ non-resident holders, and $75.99 \%$ resident normal families. Therefore, according to the latest agriculture census of Iran, non-resident holders 
make considerable part of agriculture holders. Besides, the results from agriculture census in 2003 reveal that the total number of agriculture holders is 4281543 including $0.19 \%$ official companies and institutes, $0.84 \%$ non-resident normal families, $18.95 \%$ non-resident holders, and $80.02 \%$ resident normal families. Comparing the number of agriculture holders in 2003 and 2014 shows that the total number of holders decreases in 2014 , although the number of non-resident holders increases from $18.95 \%$ to $23.39 \%$ (Table 1 ).

The increase of non-resident agriculture holders is mainly due to the increase in rural- urban migration, rural-urban linkage, easy and affordable access to rural areas and economic and non-economic motivations to keep ownership among the individuals who have migrated from rural areas; they are reluctant to sell and assign the ownership of agricultural lands to resident farmers. It also may be due to recreational and leisure motivations among non-resident holders in which the holdings are mainly as gardens; non-resident holders go to rural areas to spend their holidays. In some cases, social and cultural dependencies of immigrants to the rural areas make them keep their ownership. Generally, different ways leading to the advent of non-resident agriculture holders in rural areas are as following:

1. The migration of rural population from a rural areas to a urban regions and keeping the ownership of agriculture lands with the goals like possible return to the village, recreational and leisure goals, supporting family legacy, investment and making money.

2. Buying real estates from Rural residents by urban and non-native individuals with leisure and recreational goals, investment in real estates and profit, and in some cases, investment in the production of crops and livestock.
Studying non-resident holders across the provinces in 2014 reveals that Kerman, Gilan and Mazandaran have the highest number of non-resident agriculture holders respectively, while Qom, Hormozgan and Chahar Mahal va Bakhtiari have the lowest number of non-resident agriculture holders respectively.

Furthermore, the ratio of a non-resident holder to all holders reveals that Yazd, Alborz, and Semnan have the most non-resident holders respectively, while Hormozgan, Sistan va Balouchestan and Chahar Mahal va Bakhtiari have the least ratio of non-resident agriculture holder respectively. The comparison of non-resident agriculture holders in 2 census, 2003 and 2014, shows that both the number and the ratio of non-resident agriculture holders to total agriculture holders has increased during this period in a majority of cities in Iran. In spite of the decrease in the number of non-resident agriculture holders in some provinces like Tehran, Khorasan Razavi, Kerman, Fars, and Khouzestan, the ratio of all agriculture holders is still increasing. Sistan va Balouchestan and Hormpzgan are the only two provinces in which both the number of non-resident agriculture holders and its ratio to all agriculture holders decreases in the period (Table 2 \& Figure 1).

\section{The Features of Non-resident Agriculture Holders in the County level}

The ratio of a non-resident holder to all agriculture holders across the counties of Iran proves that counties like Aboumousa, Jask, Khamir, Sirik, Parsian, Qeshm, Qasr-e-Qand, Chabahar, Bandar Lengeh, and South Roudbar have the lowest ratio of non-resident agriculture holders, while the counties such as Anar, Taleqan, Garmsar, Khatam, Sorkheh, Bafgh, Sarayan, Rafsanjan, Damavand, and Aran and Bidgol have the most ratio of non-resident agriculture holders respectively (Table 3).

3. Assigning state lands and natural resources to interested individuals, entrepreneur, and non-local investor in rural areas.

Table 1. Share of each types of holders in the count of agricultural holders (2003-2014)

\begin{tabular}{ccccccc}
\hline Year & $\begin{array}{c}\text { Count/ } \\
\text { percent }\end{array}$ & $\begin{array}{c}\text { official companies and } \\
\text { institutes }\end{array}$ & $\begin{array}{c}\text { non-resident nor- } \\
\text { mal family }\end{array}$ & $\begin{array}{c}\text { non-resident } \\
\text { holders }\end{array}$ & $\begin{array}{c}\text { resident normal } \\
\text { families }\end{array}$ & Total \\
\hline \multirow{2}{*}{2003} & count & 9028 & 16077 & 943260 & 3064102 & 4032467 \\
& percent & $0 / 22$ & $0 / 40$ & $23 / 39$ & $75 / 99$ & 100 \\
\multirow{2}{*}{2014} & count & 8008 & 36007 & 811548 & 3425980 & 4281543 \\
& percent & $0 / 19$ & $0 / 84$ & $18 / 95$ & $80 / 02$ & 100 \\
\hline \multirow{2}{*}{ Source: Statistical Centre of Iran, 2003 \& 2014 } & & & & JSRD J J
\end{tabular}


Table 2. Count and percent of non-resident agriculture holders in provinces level (2014 \& 2003)

\begin{tabular}{|c|c|c|c|c|c|}
\hline \multirow{2}{*}{ Row } & \multirow{2}{*}{ province } & \multicolumn{2}{|c|}{2014} & \multicolumn{2}{|c|}{2003} \\
\hline & & Count & percent & Count & percent \\
\hline 1 & Qom & 3562 & $30 / 36$ & - & - \\
\hline 2 & Hormozgan & 5167 & $7 / 37$ & 8588 & $8 / 94$ \\
\hline 3 & Chaharmahal and Bakhtiari & 7757 & $11 / 75$ & 5199 & $7 / 88$ \\
\hline 4 & Bushehr & 11146 & $28 / 00$ & 7034 & $14 / 89$ \\
\hline 5 & Zanjan & 12246 & $14 / 75$ & 7657 & 9/07 \\
\hline 6 & Sistan and Baluchestan & 13676 & $8 / 11$ & 14743 & $8 / 69$ \\
\hline 7 & Alborz & 14670 & $48 / 81$ & - & - \\
\hline 8 & North Khorasan & 15473 & $18 / 97$ & 13104 & $15 / 92$ \\
\hline 9 & Markazi & 15795 & $19 / 89$ & 13162 & $14 / 40$ \\
\hline 10 & Qazvin & 16319 & $21 / 11$ & 13997 & $17 / 41$ \\
\hline 11 & Kohgiluyeh and Boyer-Ahmad & 17773 & $26 / 69$ & 7928 & $13 / 34$ \\
\hline 12 & Hamadan & 18330 & $15 / 62$ & 17487 & $12 / 28$ \\
\hline 13 & Ilam & 19487 & $36 / 40$ & 16264 & $28 / 96$ \\
\hline 14 & Golestan & 19886 & $16 / 01$ & 15772 & $11 / 50$ \\
\hline 15 & Semnan & 20772 & $45 / 86$ & 13277 & $34 / 29$ \\
\hline 16 & South Khorasan & 22546 & $27 / 27$ & 12636 & $24 / 48$ \\
\hline 17 & Tehran & 22822 & $43 / 32$ & 33782 & $39 / 07$ \\
\hline 18 & Ardabil & 25439 & $22 / 63$ & 18524 & $16 / 97$ \\
\hline 19 & Kurdistan & 29935 & $26 / 45$ & 16623 & $15 / 04$ \\
\hline 20 & Khuzestan & 30401 & $18 / 39$ & 30631 & $16 / 09$ \\
\hline 21 & East Azerbaijan & 34737 & $14 / 69$ & 26526 & $10 / 89$ \\
\hline 22 & Lorestan & 34973 & $25 / 88$ & 26203 & $20 / 28$ \\
\hline 23 & Kermanshah & 39167 & $31 / 30$ & 37251 & $26 / 73$ \\
\hline 24 & Isfahan & 40294 & $23 / 47$ & 37951 & $18 / 65$ \\
\hline 25 & Yazd & 40655 & $53 / 35$ & 29262 & $34 / 55$ \\
\hline 26 & West Azerbaijan & 43925 & $21 / 96$ & 31645 & $15 / 48$ \\
\hline 27 & Fars & 47178 & $20 / 22$ & 51577 & $18 / 53$ \\
\hline 28 & Razavi Khorasan & 67263 & $19 / 90$ & 86905 & $22 / 03$ \\
\hline 29 & Mazandaran & 77977 & $24 / 21$ & 63394 & $19 / 05$ \\
\hline 30 & Gilan & 83398 & $27 / 47$ & 61016 & $19 / 49$ \\
\hline 31 & Kerman & 90491 & $36 / 22$ & 93410 & $36 / 13$ \\
\hline 32 & Total & 943260 & $23 / 39$ & 811548 & $18 / 95$ \\
\hline
\end{tabular}




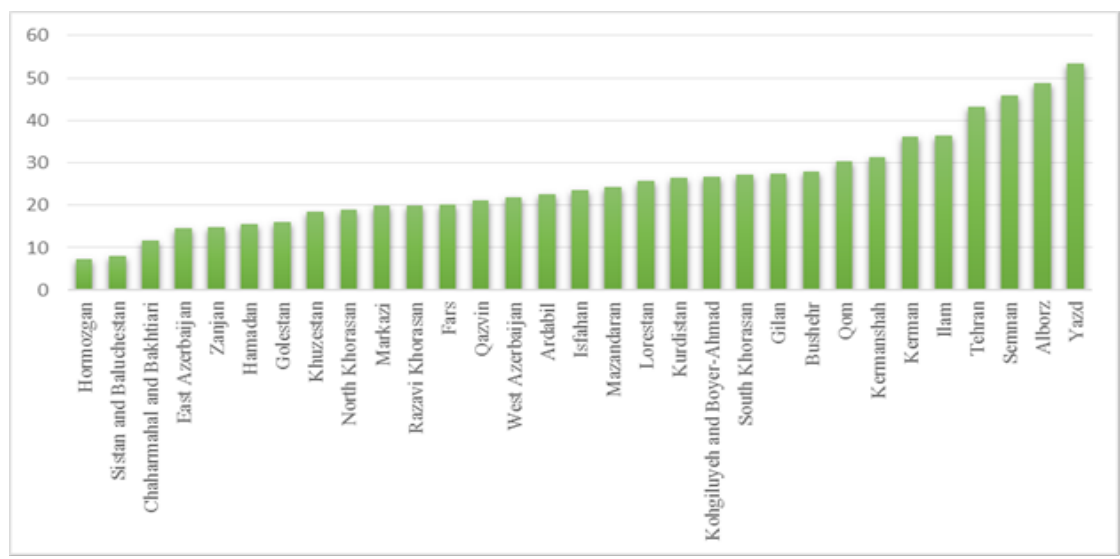

Figure 1. Ratio of non-resident agriculture holders in provinces level (2014)

Table 3. Counties with the lowest and Most Ratio of non-resident agriculture holders -2014

\begin{tabular}{cccccc}
\hline \multicolumn{2}{c}{ Lowest ratio of non-resident agriculture holders } & \multicolumn{2}{c}{ Most ratio of non-resident agriculture holders } \\
\hline County & Province & Ratio & County & Province & Ratio \\
\hline Aboumousa & - & Anar & Kerman & $77 / 75$ \\
Jask & $0 / 05$ & Taleqan & Alborz & $70 / 67$ \\
Khamir & Hormozgan & $0 / 06$ & Garmsar & Semnan & $69 / 68$ \\
Sirik & $0 / 08$ & Khatam & Yazd & $69 / 44$ \\
Parsian & & & Sorkheh & Semnan & $69 / 42$ \\
Qeshm & & & Bafgh & Yazd & $68 / 79$ \\
Qasr-e-Qand & Sistan and Bal- & $1 / 10$ & Sarayan & South Khorasan & $68 / 45$ \\
Chabahar & uchestan & $1 / 11$ & Rafsanjan & Kerman & $68 / 39$ \\
Bandar Lengeh & Hormozgan & $1 / 14$ & Damavand & Tehran & $66 / 61$ \\
South Roudbar & Kerman & $1 / 82$ & Aran and Bidgol & Isfahan & $65 / 62$ \\
\hline
\end{tabular}

Source: Statistical Centre of Iran, 2014

\section{Spatial Distribution of Non-resident Agriculture Holders}

The simple map of spatial dispersion for non-resident agriculture holders illustrate that some regions in the center, north, and west of Iran have high values of nonresident holders, while some regions in the south, southeast, east, northeast, northwest, southwest and some interior parts of Iran have low values of non-resident holders. However, this map does not provide significant information about spatial distribution of non-resident agriculture holders due to ignoring spatial autocorrelation of the studying phenomenon, adjacency relationship and the distance among the studying features (Figure 2). As a result, it is necessary to use spatial statistic to provide significant spatial analyses.
Spatial autocorrelation has been applied to determine the spatial pattern, whether clustered or random, of nonresident agriculture holders across the counties of Iran. Figure 3 presents the findings from spatial correlation. In fact, strong autocorrelation takes place when the values of a variable are geographically adjacent and have relationship. If the features or their values are distributed randomly in the region, it will be proved that they have no relationship. The findings from spatial autocorrelation show that there is a significant clustered pattern across the counties in Iran based on the variable of non-resident agriculture holders. As a matter of fact, Morans statistic is 0.305 which is near +1 proving the existence of a clustered pattern. Furthermore, $\mathrm{z}$ and $\mathrm{p}$ values are 16.51 and 0 respectively which prove the existence of clustered pattern and reject random spatial pattern of non-resident 
agriculture holders with 99\% confidence level. As standard statistic $\mathrm{z}$ is located in right red sequence of normal distribution, the clustered pattern of non-resident agriculture holders is recognizable.

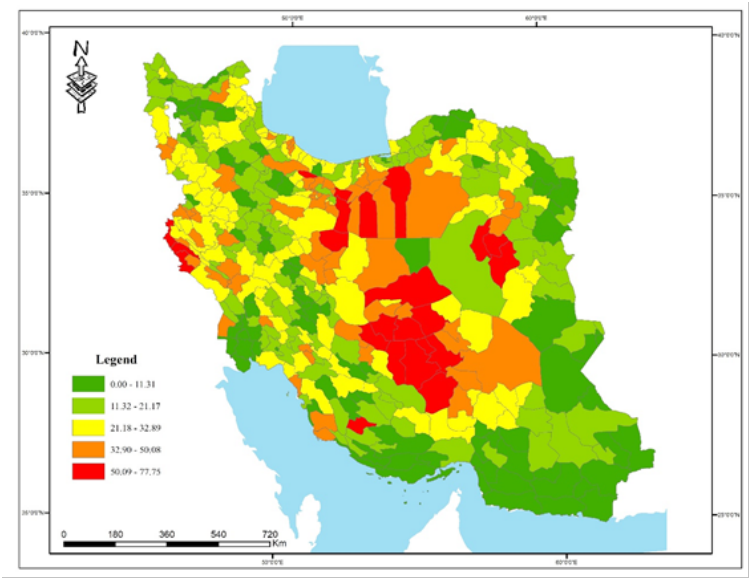

Figure 2. Spatial distribution of nonresident agriculture holders

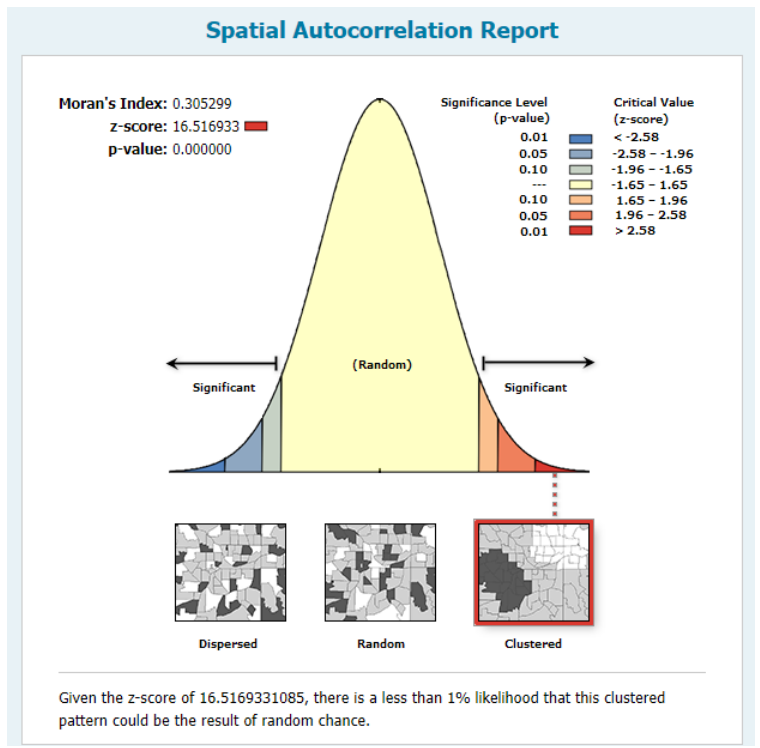

Figure 3. Spatial autocorrelation (General Mo- 0 JSRD ran's statistic) based on the ratio of non-resident agriculture holders

High-low clustering is applied to determine whether high or low values of non-resident agriculture holders have made the cluster. In this method, if $\mathrm{z}$ is positive, it is concluded that high values of the studying feature have made the cluster. Besides, if $\mathrm{z}$ in negative, it is proved that low values of the studying feature have made the cluster. The findings indicate that $\mathrm{z}$ value is positive and equals to 5.49 , and $\mathrm{p}$ value is zero. Therefore, it is concluded that high values of non-resident agriculture holding vari- able are arranged with $99 \%$ confidence level across the counties of Iran making a cluster. Furthermore, as Figure 4 depicts, since standard statistic $\mathrm{z}$ is located in right red side of normal distribution, it is proved that the regions with high values are next to each other making a cluster.

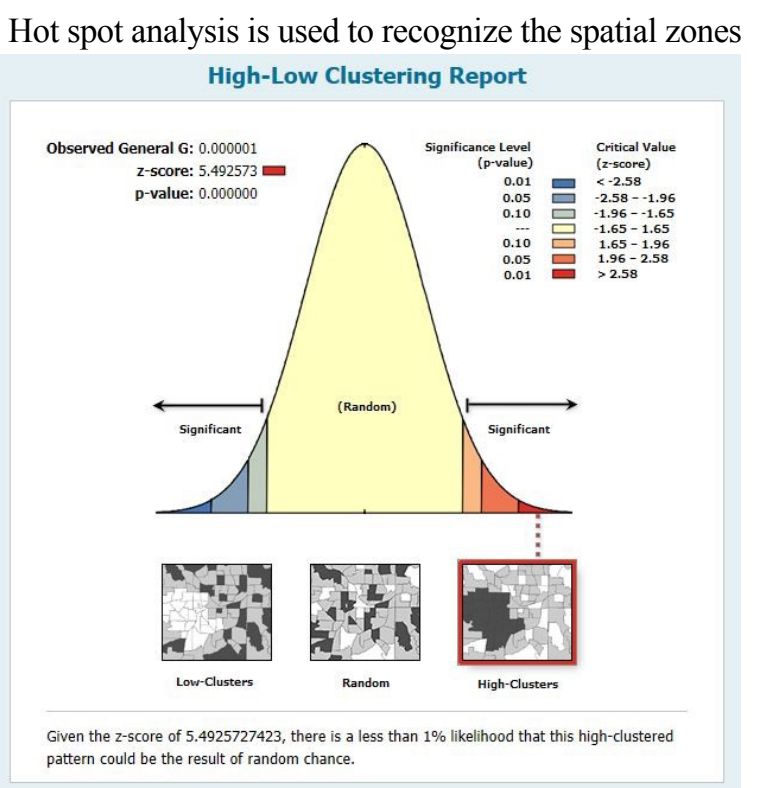

Figure 4. Analysis of high / low clustering based on non-resident agriculture holders

OJSRD

containing the clusters with high and low values which have spatial correlation. This tool looks at each feature in the frame of neighboring features. A feature is not able to make either a hot spot or cold spot alone. In fact, a feature is recognized as a hot or cold spot provided that not only the feature itself but also the neighboring ones are hot or cold; they are statistically significant. As Figure 5 shows, blue areas are the ranges in which the low values related to non-resident agriculture holder variable have gathered making a cold cluster. Moreover, red areas are the ranges in which high values of non-resident agriculture holders have gathered making hot clusters. The findings from hot spot analyses indicate the existence of 2 hot clusters with high values of non-resident agriculture holders. The first cluster matches central Iran and some northern regions of Iran including Yazd, Kerman, Esfahan, Semnan, Qom, Tehran, Alborz, Qazvin, Mazandaran, and Gilan. Second cluster matches the west of Iran including Ilam, Lorestan and Kermanshah. There are different factors leading to high non-resident agriculture holders. For example, in some regions like northern and central provinces such as Mazandaran, Gilan, Tehran, Alborz, Qazvin, Qom and Semanan the expanded recreational and leisure uses and near distance to Tehran are the most effective factors leading to high non-resident agriculture 
holders. In other words, favorable weather and easy access from urban centers to rural areas increase the number of non-resident agriculture holders; this kind of utilization is mainly like a garden. This utilization is done in 2 main forms. In the first form, the holders are native individuals owning lands who are living in rural areas. They keep their ownership after their migration to urban centers. The main motivation is recreational usages and other cases like doing limited agricultural activities, and making profit. In the second form, the holders are non-native individuals out of rural areas who buy lands and gardens due to favorable weather. In fact, the main motivation is recreational usages. In some other regions like Yazd, Esfahan, and Kerman, the effective factors on high number of non-resident holders are different from the first type. The main factor for this type is high rate of migration from rural areas to urban centers either inside or outside the province. These immigrants have kept their ownership to return, maintain family legacy, have economic motivation, do some agricultural activities, and make a profit. The effective factors on the number of non-resident agriculture holders are also different in the western part of Iran including high rate of unemployment, non-affordable agricultural activities as a way of living. These factors, eventually, lead to an increase in migration from rural areas to urban centers. Besides, various economic and non-economic motivations make ownership maintenance in these regions. In this way, the farmers benefit from their agriculture lands in 2 ways. In the first form, due to either low distance between the land and the owner's house or the popularity of dry farming which does not need the long presence of the farmer, the owner personally does agricultural activities. Generally, the findings from hot spot analyses reveal that forming focus hotspots of non-resident agriculture holders matches the provinces which have the highest urbanization rate and migration from rural regions to central centers. 10 provinces with the highest urbanization rate including Qom with the rate 95.18, Tehran with the rate 93.86, Alborz with the rate 92.64, Esfahan with the rate 88.03 , Yazd with the rate 85.35 , Semnan with the rate 79.80, Markazi with the rate 76.94, Khouzestan with the rate 75.53, Kermanshah with the rate 75.43 and Qazvin with the rate 74.75 completely match with hotspots of non-resident agriculture holders. In other words, there is a direct relationship between non-resident agriculture holders and urbanization rate. As a matter of fact, the higher urbanization growth in hotspots is, the more nonresident agriculture holders are (Rezvani et al., 2013; Mansourian et al., 2018).

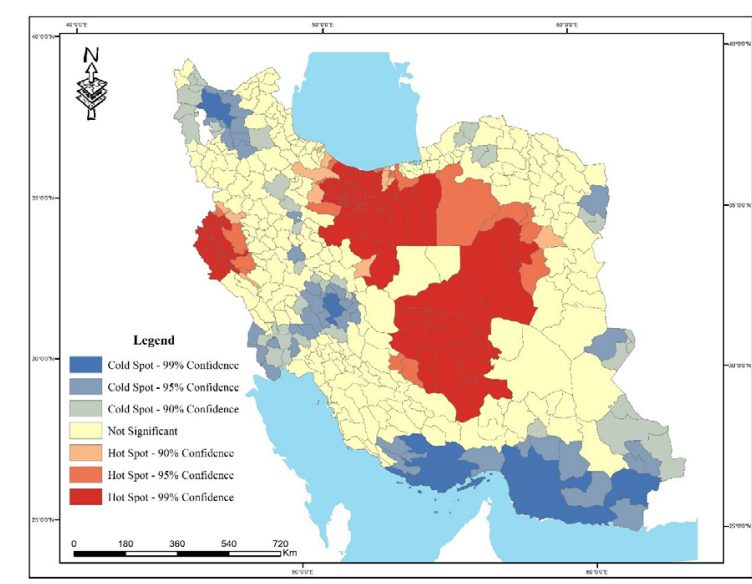

Figure 5. Hot and cold clusters based on non-resident agriculture holders

\section{Discussion}

The phenomenon of owners and non-resident agriculture holders is different from the phenomenon of absent owners which was used to exist before land reforms. Non-resident holders are the result of the factors like rural-urban migration, the investment of urban dwellers in agriculture and leisure-recreational motivations to own the agricultural ownership in rural regions.

Spatial distribution of non-resident agriculture does not have an equal status. In fact, some provinces like Yazd, Alborz, and Semnan have high values of non-resident holders, while the provinces like Hormozgan, Sistan va Balouchestan and Chahar Mahal va Bakhtiari have low values of non-resident holders. The ratio of non-resident agriculture holders is influence by different factors like the increase in rural -urban migration rate which is due to inappropriate employment, high rate of unemployment in rural areas, and non-affordable agricultural activities to make a living. The other effective factor is the development of rural-urban linkages, simple transportation and easy movement between rural areas and urban centers.

Lack of uniform spatial distribution of non-resident agriculture holders is seen more intensely across the counties of Iran, as the counties like Aboumousa, Jask, Khamir, Sirik, Parsian, Qeshm, and Bandarlengeh in Hormozgan Province, Chabahar and Qasr-e-Qand in Sistan va Balouchestan Province, and South Roudbar in Kerman Province have the lowest ratio of non-resident agriculture holders. Moreover, the counties Anar and Rafsanjan in Kerman Province, Taleqan in Alborz, Garmsar and Sorkheh in Semnan Province, Khatam and Bafgh in Yazd Province, Sarayan in southern Khorasan 
Province, Damavand in Tehran Province, and Aran and Bidgol in Esfahan Province have the highest ratio of non-resident agriculture holders.

Spatial statistic methods are used to recognize the hotspots of non-resident agriculture holders. The findings indicate 2 clusters with high values of non-resident agriculture holders. A cluster, recognized as the main hotspot of non-resident agriculture holders, contains a wide spatial area of central and northern regions including provinces like Yazd, Kerman, Esfahan, Semnan, Qom, Tehran, Alborz, Qazvin, Mazandaran and Gilan. The other cluster is recognized for the western regions of Iran which has a narrower area than the first one including Kermanshah and Kordestan and some counties in Hamedan, Lorestan, Ilam and Khouzestan provinces. The factors making these hotspots are different. For example, recreational and leisure usages are the most effective factors in making hotspots of non-resident holders in northern and some central provinces like Mazandaran, Gilan, Qazvin, Alborz, Tehran, Semnan and Qom. The ratio of non-resident agriculture holders has increased due to good weather condition, close distance to Tehran megacity and other urban centers in the aforesaid provinces. However, for central provinces like Yazd, Kerman, and Esfahan, high rate of rural migration and near distance to urban centers increase the ratio of nonresident agriculture holders. In western regions, hotpot is made due to inappropriate rural employment, low job opportunities in rural areas, high unemployment rate, seasonal jobs and non-affordable agricultural activities which lead to the increase in the rate of rural migration to urban centers and the ratio of non-resident agriculture holders. The direct relationship between urbanization rate and the ratio of non-resident agriculture holders are the main points in spatial analysis of non-resident agriculture holders. In other words, the provinces with high urbanization rate are located in hotspots of non-resident agriculture holders with high values. These findings are in accordance with the findings from Mansourian et al (2018) who have studied the spatial analysis of rural floating employed population. They have considered unemployment and inappropriate climatic conditions in rural areas like drought, which has decreased the efficiency of agriculture section, as the effective factors on increasing daily commuting of villagers in rural areas and near urban areas.

The ratio of holders across the provinces of Iran indicate that the average of non-resident agriculture holder ratio to total agriculture holders is $25.37 \%$; a quarter of all agriculture holders. This value is fluctuating from $7.37 \%$ in Hormozgan Province to $53.35 \%$ in Yazd.
Moreover, the ratio of non-resident holders to total agriculture holders in the cities of Iran shows that the ratio of non-resident agriculture holders is fluctuating from $0 \%$ in Aboumousa in Hormozgan Province to $77.75 \%$ in Anar in Kerman Province. The average of non-resident agriculture holders ratio to all agriculture holders across the counties is $22.92 \%$. The aforesaid values show high ratio of non-resident agriculture holders across the provinces and counties of the Country having different consequences. One of the problems of agriculture section in Iran is lack of proportion between the number of agriculture holders and the land they have. In fact, not only is the average area of holding low, but also the lands are dispersed. According to public census in 2014, the area of agricultural lands in Iran is $16476609 \mathrm{Ha}$, while the number of agriculture holders is 4032467 ones (Iran Statistic Center, 2014). Therefore, each holding can have $4 \mathrm{Ha}$. Besides, dispersed lands lead to the decrease in productivity and yield per hectare. Non-resident holders decrease the area of agriculture lands, for they are not interested in assigning or selling their agricultural lands to resident holders leading to the emergence of smallholding, increase in production cost and non-affordable agriculture lands. These findings are in accordance with the findings of Shokati Amghani et al. (2019). They consider smallholding and land dispersion as 2 effective factors on production cost. As a matter of fact, there is a direct relationship between the number of holders and smallholding. As a result, smallholding is very common in the regions with high number of holders. Gilan, Mazandaran, Yazd and Alborz with 0.69, 1.04, 1.51, 1.67 ha (Iran Statistic Center) respectively are the ones which have the lowest area of land available. They are in hotspots of non-resident holders. Small agriculture lands are like a barrier stopping agricultural development and rural development. In other words, this phenomenon weakens the balance between rural population and agriculture capacity for production and employment leading to the increase in migration rate from rural areas to urban centers. Furthermore, since non-resident holders convey a part of resources, rural wealth, and the profit from agriculture activities to urban centers, they prevent flowing of profit in rural development. Moreover, they are also reluctant to invest in villages and agriculture activities. These findings are in accordance with the findings from Mekaniki (2011) in which the researcher believes that rural habitats are affected economically-socially by the interaction between urban and rural areas. According to Mekaniki (2011), urbanization, which is influenced by economic factors like the decrease in capitation income and job opportunities, increases migration current and unstable rural habitats. Generally, it can be said that non- 
resident agriculture holders have a negative role in the process of sustainable rural development. However, if the available lands for non-resident agriculture holders, which is $25 \%$ of all agriculture holders, are assigned to resident agriculture holders, the available lands for resident holders in rural areas will increase leading to more profitability for rural residents and, more investment and more structural reforms. It, eventually, develops agriculture activities and rural sustainable development. These findings are in accordance with the findings from Badri et al. (2011) in which they reveal that the increase in available areas under cultivation of rural holders can not only provide nutrition security for poor rural residents, but also affect social cooperation of rural residents. It can also accelerate the access to rural sustainable development. Generally, careful studies on the factors which increases non-resident agriculture holder in rural areas and explaining the possible consequences economically, socially, culturally, environmentally, and spatially requires separate research. However,it is accepted that this phenomenon has inappropriate effects on rural and agricultural sustainability of Iran.

\section{Acknowledgements}

This research did not receive any specific grant from funding agencies in the public, commercial, or not-forprofit sectors.

\section{Conflict of Interest}

The authors declared no conflicts of interest.

\section{References}

Abrahamian, E .(1996). Iran Between Two Revolutions. Translation: Ahmad Gol Mohammadi and Mohammad Ebrahim Fatahi. Tehran, Ney Publishing.

Ashraf, A. (2004). From the White Revolution to the Islamic Revolution. Translation: Mohammad Salar Kasraie, Matin Research Journal, No. 22, 109-141.

Azkiya, M. (2008). Sociology of Rural Development and Rural Underdevelopment of Iran. Tehran, Etelaat.

Badri, S, A. Eftekhari, A. Salmani, M. Bahmand, D. (2011). The Role of Agricultural (Family) System in Rural Sustainable Development (Case Study: Ghirokarzin County, Fars Province). Human Geography Research, No. 76, 33-48.

Chen, H., \& Yada, R. (2011). Nanotechnologies in agriculture: new tools for sustainable development. Trends in Food Science \& Technology, 22(11), 585-594.
Chayanov, A. V. (1977). On the theory of non-capitalist economic systems. The theory of peasant economy, 1-28.

Cliff, A. D., \& Ord, J. K. (1981). Spatial processes: models \& applications. Taylor \& Francis.

Ehlers, E. (2001). Capitalism and Urban Development in the Islamic East (Iran Sample). Translation: Abbas Saeidi, RuralUrban- Nomads. Tehran, Monshi.

Ehlers, E. (2010). Traditional rural-urban relations in Iran.Translation: Abbas Saeidi. Tehran, Mehr Minoo,

FAO. (1991). Den Burg Manifesto and Agenda on Sustainable Agriculture and Rural Development. Congress of Agriculture and Environment, Den Burge, The Netherlands.

Galeski, B., \& Wilkening, E. A. (1987). Family farming in Europe and America. Westview Press.

Gong, J., \& Lin, H. (2000). Sustainable development for agricultural region in China: case studies. Forest Ecology and Management, 128(1-2), 27-38.

Getis, A., \& Ord, J. K. (1996). Local spatial statistics: an overview. Spatial analysis: modelling in a GIS environment, 374, 261-277.

Hosseini, Gh. (2009). Vulnerability and Development of the Agricultural Holders System in Iran. Strategic Journal, No. 52, 129-148.

Hooglund, E. (2002). Land and Revolution in Iran, 1960-1980. Translation: Firoozeh Mohajer in Iran, first edition, Shirazeh Research Journal.

Kargar Esfand Abadi, K. Yousefi, A. Rahimi, A. (2017). Social Stratification in Villages of Iran Before and After Land Reform (1963). Journal of Elite Engineering Sciences, 4, 1 -21.

Kumari, M., Sarma, K., \& Sharma, R. (2019). Using Moran's I and GIS to study the spatial pattern of land surface temperature in relation to land use/cover around a thermal power plant in Singrauli district, Madhya Pradesh, India. Remote Sensing Applications: Society and Environment, 100239.

Lambton, A,K,S. (1983). Landlord and peasant in Persia.Translation: Manouchehr Amiri, Third Edition. Tehran, Scientific and Cultural Publishing Center.

Leavy, J., \& Smith, S. (2010). Future farmers: youth aspirations, expectations and life choices. Future Agricultures Discussion Paper, 13, 1-15

Leunufna, S., \& Evans, M. (2014). Ensuring food security in the small islands of Maluku: a community genebank approach Journal of Marine and Island Cultures, 3(2), 125-133.

Mansourian, H. Rezvani, M, R. Saadi, S. (2018). Spatial Analysis of Rural Floating Population in Urban Areas of Iran. Journal of Rural Research, 8(4), 621-634.

Mekaniki, J. (2011). Urban and Rural Social Relations and Population Instability of Rural Settlements Case Study: Birjand Central Sector. Khorasan Socio-Cultural Studies, No. 19, 161140.

Mitchel, A. (2005). The ESRI Guide to GIS analysis, Volume 2: Spartial measurements and statistics. ESRI Guide to GIS analysis. 
Peeters, A., Zude, M., Käthner, J., Ünlü, M., Kanber, R., Hetzroni, A., ... \& Ben-Gal, A. (2015). Getis-Ord's hot-and coldspot statistics as a basis for multivariate spatial clustering of orchard tree data. Computers and Electronics in Agriculture, $111,140-150$.

Razvani, M, R. Mansourian, H. Mahmoudian Zamaneh, M. Heidarian Mohammad Abadi, R. (2013). Spatial Analysis of Unemployment in Urban and Rural Areas of Iran Using the Spatial Data Exploratory Analysis Approach. Physical-Spatial Planning , 1(3), 48-37.

Saeidi, A. (2011). Principles of Rural Geography. Tehran, Samt.

Shatri, M. Hajipour, M. Nejati, B. Dezgi, A. (2013). Economic Impacts of Agricultural Production Cooperatives on Rural Households (Case Study: Agricultural Production Cooperatives of Birjand County). Journal of Khorasan Social Cultural Studies, No. 2,. 109-128.

Shahverdi, Sh. (1994). Land Reform and Its Consequences, M.Sc., Imam Sadegh University.

Shokati Amghagani, M. Kalantari, K. Asadi, A. Shaban Ali Femi, H. (2019). Measuring the Rate of Fragmentation and Dispersion of Arable Lands in East Azarbaijan province, Iran. Journal of Rural Research, 9(4), 523-535.

Spedding, C. (2012). An introduction to agricultural systems. Springer Science \& Business Media.

Statistics Center of Iran (2014). General Agricultural Census.

Statistics Center of Iran (2003). General Agricultural Census.

Taleb, M. (1994). Sociological Issues and Barriers to Rural Development in Iran. Social Science Letter, No. 7, pp.98-117.

Taleb, M. Anbari, M. (2005). Rural Sociology (Dimensions of Change and Development in Iran Rural Society). Tehran, Tehran University.

Toupchi, B. Rostami, F. Khodabakhshi, A. (2011). Comparison of Water Wheat Production Components of Peasant, Commercial and Cooperative Production Systems in Kurdistan Province. Iran Journal of Economics Research and agricultur Development, 42(2) , 219-229.

Xu, X., Hou, L., Lin, H., \& Liu, W. (2006). Zoning of sustainable agricultural development in China. Agricultural Systems, $87(1), 38-62$

Yang, Q., Zhang, H., Bai, W., \& Liu, W. (2018, June). CountyScale Migration Attractivity and Factors Analysis. In 2018 26th International Conference on Geoinformatics (pp. 1-7). IEEE. 
